\title{
ALTERNATIVE TEACHING METHOD: THE NEEDS ASSESSMENT OF INTERACTIVE E-CONTENT APPLICATION IN TEACHING ART HISTORY COURSE
}

\author{
Noor A'yunni Muhammad', Salwa Ayob², Ishak Ramli ${ }^{3}$ \\ ${ }^{1}$ Mrs., Faculty of Art \& Design, Universiti Teknologi MARA, Perak Branch, MALAYSIA, \\ noora691@perak.uitm.edu.my \\ ${ }^{2}$ Dr., Faculty of Art \& Design, Universiti Teknologi MARA, Perak Branch, MALAYSIA, \\ ${ }^{3}$ Mr., Faculty of Art \& Design, Universiti Teknologi MARA, Perak Branch, MALAYSIA, \\ ibr_86@yahoo.com
}

\begin{abstract}
The most important thing in learning arts is to understand the basic knowledge which usually it starts with the history of art. Art history plays an important role in the development of art world. It explains how art world evolves from renaissance to post-modern art and thousands of talented artist and artwork has been acknowledge decades ago. However, teaching art history comes with a lot of effort. As a matter of fact, econtent in e-learning requires creativity in teaching method, because when it comes to the nature of art history subject, it is full of text, facts and boring images. Based on this notion, this study aimed to discover the needs of alternative e-content as part of art history teaching method in education nowadays. Furthermore the study tend to discuss the literature review which will be treated as an evidence to prove the impact of alternatives e-content application in art history subject and how it influence worldwide education system. This research will encourage educators to create an e-content in e-learning of art history subject which will be one of the alternative teaching methods in teaching art history. This study will help a lot in terms of enhancing the current teaching method.
\end{abstract}

Keywords: Alternative Teaching Method, Needs Assessment, Interactive, E-Content Application, Art History

\section{INTRODUCTION}

Nowadays people tend to go online. From shopping, applying jobs, filling forms until seeking for an advice and consultancy. It shows how important the used of internet to organize our daily lifestyle including entertainment and education. In education, when it comes to the used of internet and relate it with education 
world, obviously it is related to e-content. E-content can be described as the combination of text and images which designed for web pages or can be understand as 'digital content'. Since our world has been surrounded with the advancement of technologies and gadgets, e-content approach is really effective in teaching and learning especially for art history subject. As far as everyone concern, art history are all about ancient or vintage images, and facts with loads of texts. History subject often been related to 'boring' and this is the issues that educators needs to improve in their teaching method. As per mention by previous literature, boredom usually been experience in history class and that is why it should be replaced by implementing various kind of historical activities and approach to make the subject lively and interesting (Moturi Srivinas, Prasada Rao, Digumarti Bhaskara Rao, 2004).

To support this statement, as per mention by Snjezana Koren, an important element in teaching history is to make the past alive in the minds of student, so that they will be able to visualize as if they were in the history era, hear and join them either as observer or to be part of the history maker (Snjezana Koren, 2014). This statement shows the problems that occur in the process of delivering the knowledge of art history. In this case, learning art history for art students is important to strengthening art student's thinking skills.

Since art history is all about appreciation of traditional art aesthetic, a better teaching method such as econtent should be a solution to encounter the student's interest' issues in learning art history. It doesn't matter whether e-books, application or even video as a learning tools, as long as it involves interactive physical participation from the students and effectively delivered the facts and infos, art history will be the easiest subject to be learn.

Based on this notion, this study aimed to discover the needs of e-content as part of alternative teaching method in education nowadays. Furthermore the study tend to discuss the literature review which will be treated as an evidence to prove the impact of e-content and how it influence worldwide education system

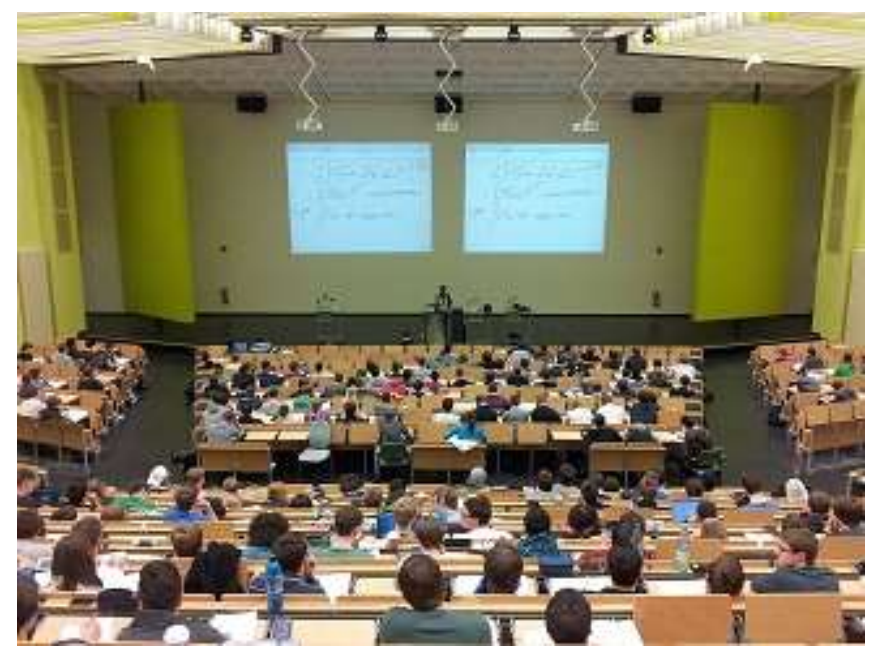

Fig 1: Current Art History Teaching Method- University Lecture

\section{THE ENVIRONMENT IN LEARNING ART HISTORY SUBJECT}

In this study, it will emphasize more on the problem that occur in art history studies. The feedback from students regarding the successful of history subject in terms of learning is not satisfying and it refers to the method of teaching which is not effective and not interesting. Problems in studying art history can be detected based from the exam result of the subject at the end of every semester. It explains how students are not able to absorb the info of art history subject through due to the requirement in learning art history subject depends on notes and essay. However, previous years have been a challenge in terms of the acceptance of e-learning within higher education and its impact for institutions, practitioner and also students (Rhona Sharpe and Greg Benfield, 2015). This is because, at that moment, when e-content approach has been introduced as part of teaching method some educators find it difficult to combine the idea of e-content with the traditional method of teaching which has been practiced for years.

However, from time to time, the advancement of technology makes our world evolved and e-content approach in education slowly been accepted in every sectors, schools and universities. Through e-content approach, it is possible to make art history class more interactive and creative. Based from the observation, 
nowadays teaching method tends to implement the face-to-face concept of teaching method. Even though today we are moving forward to the era of 2020, nowadays teaching methods are still teacher-centered where teachers or educators will dominate the whole classroom. There is nothing wrong about the traditional method, however since technology has manipulate the whole social interaction, being traditional is no longer relevant. Handout notes or lame slide presentation unable to encourage or develop an effective two-way communication between students and teachers. As been highlighted in a research paper by previous literature, in traditional teaching and learning, the responsibility rely on the educators due to the believed that student will be present in a classroom, sit and listen to the lecture brief, digest and use all of the knowledge given (Viera Boumová, 2008). These kinds of method are not suitable to art history subject referring to the education environment nowadays.

\begin{tabular}{|l|l|}
\hline Traditional Teaching Method & Advance Teaching Method \\
\hline Teacher Centered Leaning & Student Centered Learning \\
\hline Expensive & Low cost \\
\hline Wasting energy & Save energy \\
\hline \multicolumn{2}{|l|}{ Table 1: The comparison between Traditional Teaching Method and Advance Teaching Method. } \\
\hline
\end{tabular}

Referring to the table above, clearly it shows how Advance Teaching Method can benefit a lot especially in the development of education sector. Besides focusing on student centered learning, it also save cost and energy and very flexible to be implement especially in every history classes. Nowadays, education system has implemented advance teaching method as part of every syllabus in education. As an example, Powerpoint software are one of the teaching tools that helps to deliver art history content. However, this advance teaching method involving e-content still needs to be improve for the sake of the education development.

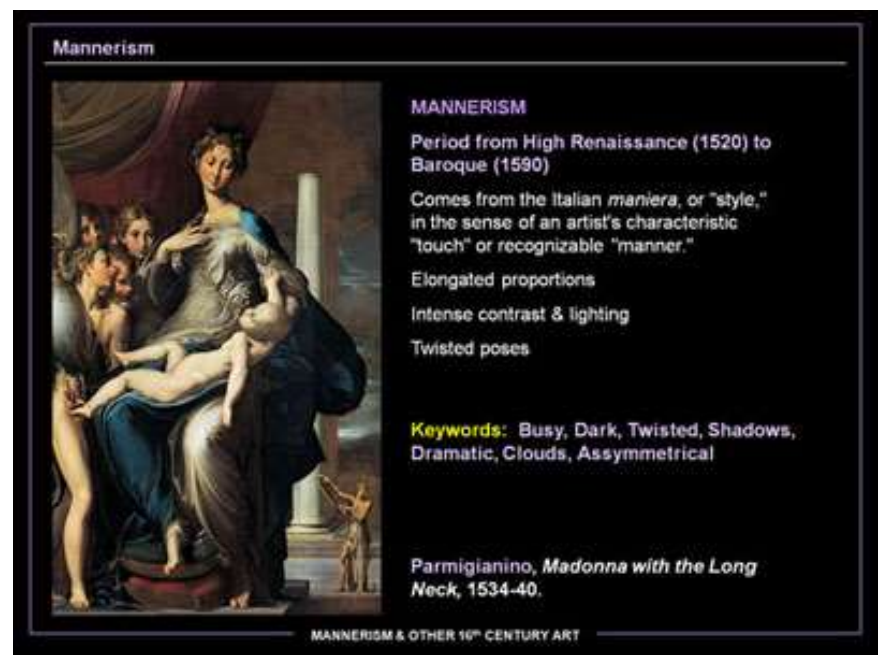

Fig 1: E-content Slide Presentation for Art History subject

\section{CURRENT NEEDS IN TEACHING WAVE: E-CONTENT APPLICATION}

In this research, the aim is to discover the needs of e-content as part of alternative teaching method in education especially in Art History subject. Furthermore the study tend to discuss the literature review which will be treated as an evidence to prove the impact of e-content and how it influence worldwide education system.

E-content create a better teaching method which will be an alternative so that in future student will enjoy their learning session in art history subject. By applying the e-content approach, not only Art history subject will develop a new perspective but It can also be a benchmark for other subject to changed their teaching method as well. In E-content approach, Interactive refers to the expansion or the development from current e-content teaching approach. As an example, if current teaching method used Authoring Tools (software) as teaching materials in teaching Art History subject, the 'alternative' should be beyond that. It should start to implement physical interactive which requires movement from the audience/students.

Physical interaction from audience/students in education is important because it shows the effectiveness of 
e-content in alternative teaching method. As far as everybody concern, e-content or electronic content has been acknowledge as a digital content which includes text, videos or images and these elements will be displayed in most of the online webpages. If E-content been enhance into the next stage by combining physical interaction such as movement as part of the teaching content, it will reflects the use of new multimedia technology by the support of internet to improve the quality of teaching and learning skills (Website source). This approach will be considered as interactive.

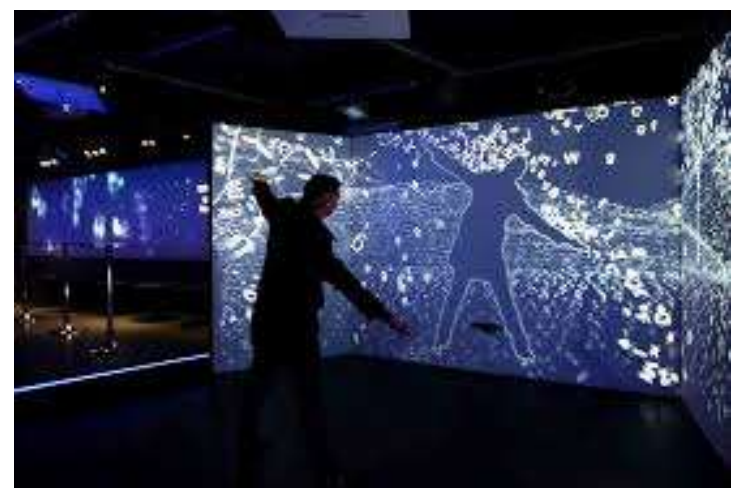

Fig 2: Sample of E-content approach which implementing the physical interactive method (Web source)

Besides the implementation of physical interaction, through the adaptation of e-content, educators able to create an online classroom exclusively for Art History subject. Online Classroom will maximize the use of online discussion board or we can identify it as message board. The use of this board will accidentally develop student's critical thinking due to the functionality is more to discussion (Anahit Ter-Stepanian, 2011). Online classroom also can be consider as an interactive in alternative teaching method due it requires communication between person through the use of internet, gadget tools, digital text and images.

The combination of e-content and education develops the knowledge of e-learning. E-learning can be described as learning session which has been delivered by electronic technology. E-content in E-learning approach are easy to implement in education system due to the cost of web servers and technical handling are more cheaper than providing classroom facilities, considering the instructor time, and student's expenses to attend the classroom (Beatrice Ghirardini,2011). On the other side, e-content in e-learning concept can be considered as the advancement of current technology whereby it contributes in terms of delivering messages and infos interactively.

\section{INTERACTIVE APPROACH IN E-CONTENT APPLICATION}

Since this research emphasizing the importance of interactive e-content in alternative teaching method it also reflecting a communication method between people. Interactive is one of the characteristic which allows relationship between computer and computer-user and at the same time responding to the technology input. In simple words, whether it is a system or even a computer program, it connected user with information (web source). E-content application in teaching art history are more to the use of power point instead of making the subject interesting by applying alternative methods in terms of subject presentation. Alternative method in e-content application can be identify as interactive media and it consist the combination of digital media with electronic text, graphics, and moving images and also sound.

This combination will build structured computerized characteristics which helps the audience to understand and interact with the content provided (England, Finney, 2011). This interactive media can be referred to animation approach, short documentaries, and advanced presentation software such as prezy. In has been proven that e-content is one of the teaching methods that helps to deliver syllabus content especially in art history content. Through the enhancement of e-content approach (by making it more interactively) in teaching method in art history subject, the study environment will be Student Centered Learning (SCL) instead of Teacher Centered Learning (TCL). This is because the application of alternative e-content application will make students interact with the environment not only emotionally but physically as well. 


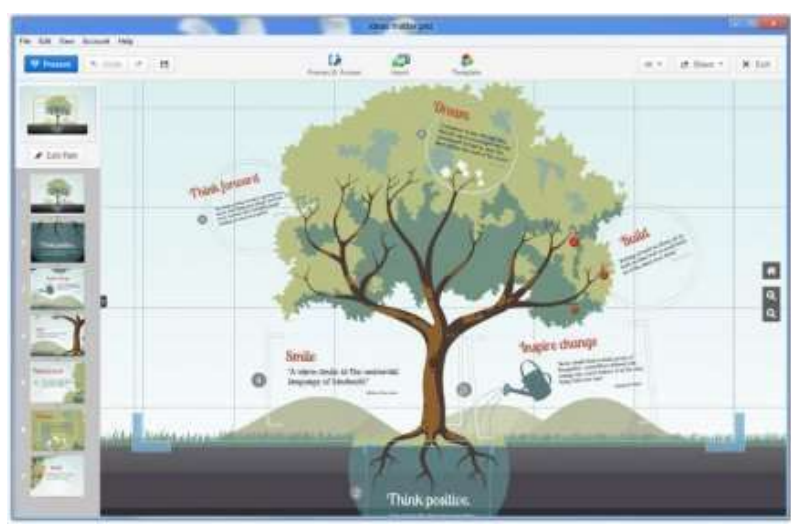

Fig 3 : The used of Prezy software in subject presentation

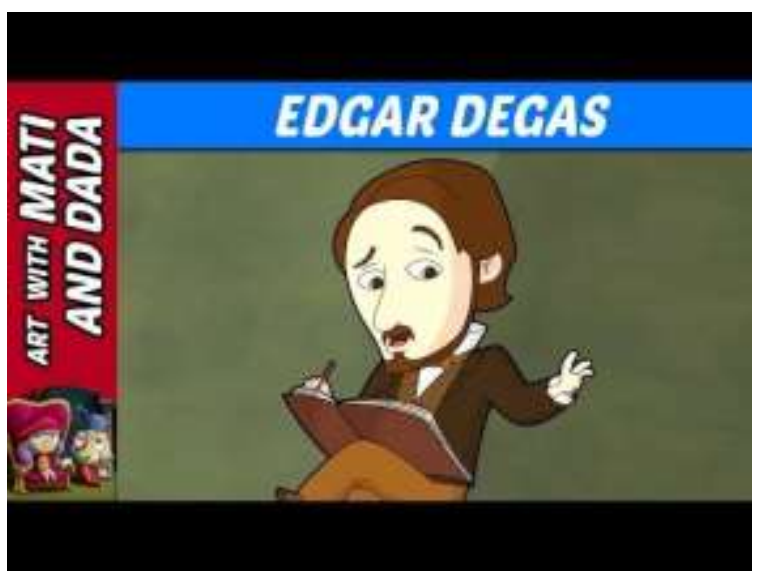

Fig 4: The Implementation of animation (Combination of digital images, texts, sounds and art history content) in Art History subject.

\section{THE NEEDS OF INTERACTIVE E-CONTENT APPLICATION IN TEACHING ART HISTORY}

Previous researcher has briefly explained why learning art history is very important for art students. With the art history information, students will learn about things that are happening today. In this case, they will train themselves to be alert about the past and current scenario of art world. Learning art history will make the students practice their art skills and develop their writing skills (Julia Murphy, 2007). Since most of university's goal is to produce researcher and academician, writing skills and knowledge about facts is a must.

However, problems with art history are, it involves a lot of texts, need to memorize a lot of picture which consists artefacts, architectural, monument or even an artworks. As per stated by Snjezana Koren in her article, she claims how history textbook plays an important role in education because textbook transfer social, cultural and political norm of one society however she explains, most of the textbook still includes only one dimensional interpretation of historical problem and in this case, it does not help students to develop their own critical thinking (Snjezana Koren, 2014). Same goes with art history. It represents the art culture and norm as well and most of art history textbook is not so easy to understand because most of the textbook are using jargon words. This is why we need our teaching method as an educator due to the evidence which strongly showing the lack of current teaching method. 


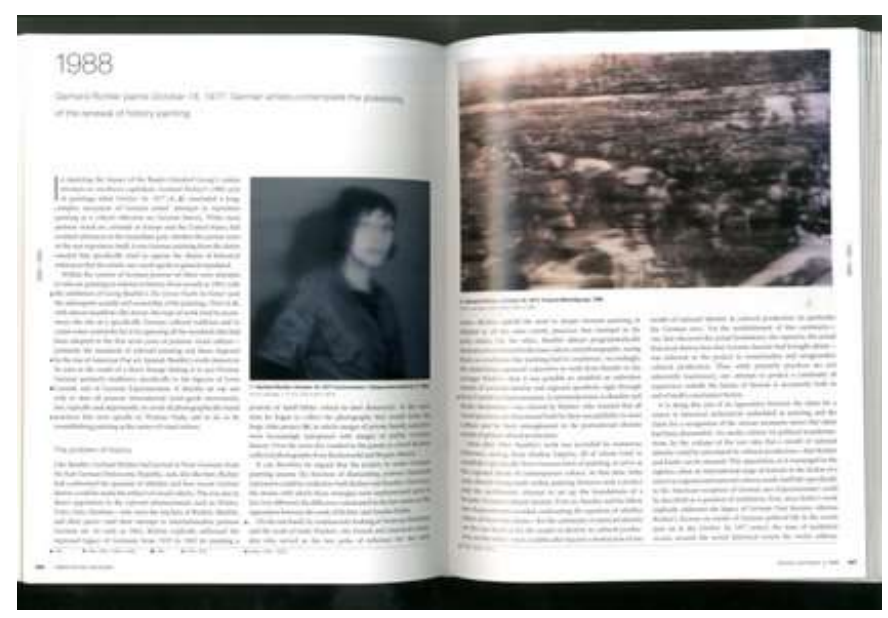

Fig 5: Previous Art History Learning tool- By Using Text Books

Along with the development of technologies, a lot of educational institutions across the world has already implemented electronic learning environments (Allison Littlejohn And Chris Pegler, 2007). This kind of environment which requires the combination of e-content, education system and technologies can be also considered as 'Blended Learning'. Nowadays, teaching methods are including electronic resources, tools and environment participation in terms of educational settings. An alternative teaching method like blended learning is challenging but it will become an essential skill for an effective teaching methods (Allison Littlejohn And Chris Pegler,2007).This statement obviously explain how blended learning might turn the table around by being an alternative method in terms of teaching art history. This is because, there is a lot of method that educator can utilize by using the concept of blended learning to improve their teaching skills in art history education. One of the way is by developing an e-book which can be access through online, and can be reach anywhere and everywhere even though the students are not in the classroom or as a reference after class.

The influence of media and technology can contributes a lot in education system because nowadays social media tools are changing the way people in this world communicate (Tonya Joosten, 2006). It is because, through social media, people are able to share ideas, and creating new networks. This kind of interaction can be part of blended e-learning as well due to the simple explanation by Allison Littlejohn and Chris Pegler (2007) blended e-learning is all about studying online with tutors as facilitators within a course through online collaboration. The online based teaching method consist downloading content to mobile devices and ebooks as a resource. When referring to online and mobile devices it will accidentally reflect the influences of media social networking. When social networking, online sources collaborating in education system it definitely will gives a new angle of perspective in alternative teaching methods. The beauty of technology arise when it is able to support collaborative learning experience, in distance or even independent of time and space (D.R. Garrison and Terry Anderson, 2003)

E-books are one of the e-content approaches which started to be implementing in education system. Kevin Wong and Paul Lam (2011) explain how e-books can be can be effective is the facilitation of teaching and learning. By implementing the e-learning approach, the students can use the e-books as part of reference materials. In University of Hong Kong, the e-books system has been implemented few years back. The ebooks methods were integrated with their curriculum that matched the weekly topics of the course. By this evidence, it shows how e-books can be part of blended learning and art history will successfully delivered by using this kind of alternatives method (Kevin Wong And Paul Lam ,2011). Kevin Wong and Paul Lam also explain how e-books which is part of e-content can be a teaching strategy. They even mention about how 'tons' of reading materials that take a lot of spaces in bookcase can now be restore in mobile devices. Besides being more effective in teaching methods, it helps in organizing space and more users friendly since students nowadays are more comfortable with technology.

\section{GUIDELINES IN DEVELOPING INTERACTIVE E-CONTENT FOR ART HISTORY SUBJECT}

To create an interactive e-content based on learning subject is not an easy task. Based on the observation that has been made, it obviously explains how interactive e-content in art history subject cannot be created by depending on information and facts only. As per mention in 'E-Content Development' article, a systematic 
and scientific approach is the most important element that should be included in the development of econtent (Lizeron Eremias, R. Subash, 2013). First step in making e-content especially in art history subject is to understand the basic knowledge on Instructional Design. Instructional Design is part of the systematic elements and also explains the reflective proses of transforming principles of learning and instruction into materials such as activities, information resources and also the assessment (Patricia L Smith, Tillman $\mathrm{J}$ Ragan, 1999)

According to Lizeron Eremias and R. Subash, in the process of making an e-content, it is important to adapt learning theories to support the instructional design. The learning theories include:

\begin{tabular}{|l|l|}
\hline Learning Theories & Function \\
\hline Cognitism & $\begin{array}{l}\text { visualize the body of the content, keep and } \\
\text { recovering the content. }\end{array}$ \\
\hline Constructivism & $\begin{array}{l}\text { supports the learner-centered approach in e- } \\
\text { learning. }\end{array}$ \\
\hline Behaviourism & $\begin{array}{l}\text { emphasize on strengthening, preservation and } \\
\text { transfer of knowledge in the e-Content } \\
\text { development. }\end{array}$ \\
\hline
\end{tabular}

Table 2: List of Learning Theories which supports the making of e-contents by Lizeron Eremias and $R$. Subash

Based on the table below, it shows that a good e-content should practice the basic learning theories such as cognitism which more on visualizing the body of e-content, preserve and improving the content. (In this case, cognitism should be all about art history content). Besides cognitism theories, constructivism theories should be considered because it supports the learner-centered approach in e-learning education system. One more basic learning theories in developing instructional design is behaviorism theories which emphasize on firming, keep and transfer the knowledge in the development of e-content. Behaviorism can also being express as physical interaction in e-content approach.

After these theories being develop into an e-content approach, creativity in developing e-content presentation interactively should also be considered as the strongest elements in terms of capturing student's attention. This statement explains why instructional designer will design solutions that are not only functional but also attractive or appealing to the students (Patricia L Smith, Tillman J Ragan, 1999). Even though the quality of teaching and learning is the main objective in e-learning, the student's involvements also will be expand through the enhanced of teaching materials. It will improve learning resources and creates a better a better communication in learning environment (Rhona Sharpe and Greg Benfield, 2005). To develop an interactive e-content, there is a model developed by previous research which can be treated as guideline. It is the ADDIE model. ADDIE stands for Analysis, Design, Development, Implementation, and Evaluation which signify a dynamic, flexible guideline for developing effective teaching tools such as econtent (Dr. K.Nachimuthu , 2012). Same goes with art history e-content development. 


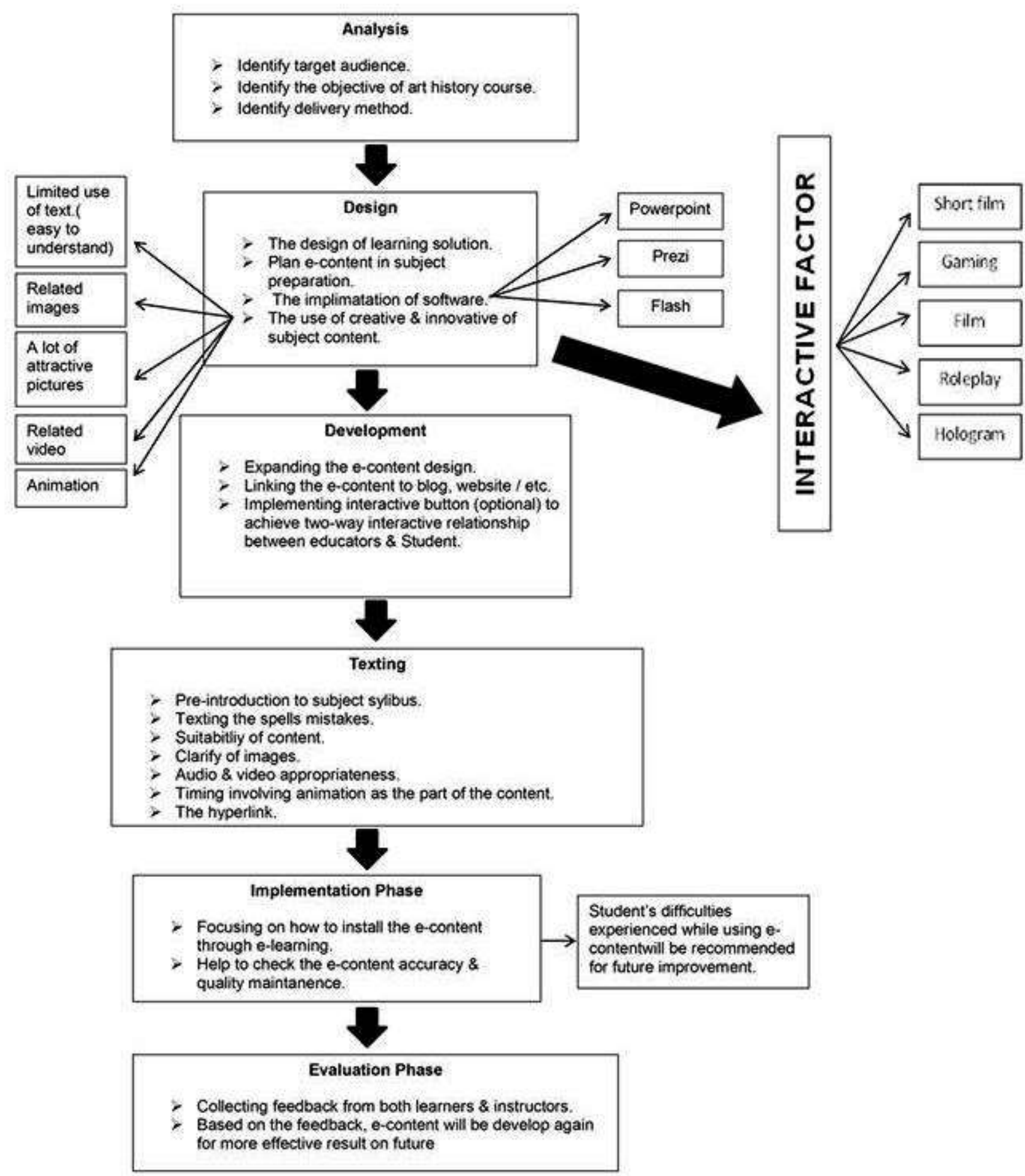

Fig 6: Art History e-content development process based on ADDIE model framework (Aldoobie, 2015)

Referring at the ADDIE model above, as per mention in design phase, the adaption of software as learning materials can expand current teaching method into a better alternative teaching method. We are living in a world which technology and internet has become part of our living culture. In the development of technology, gadgets and softwares are part of the dominant elements. In the development of e-content, software can be identified as Authoring Tools which reflects a software application to develop e-learning outcome such as econtent the function of Authoring Tools which is more to create, edit, review, and test and to construct elearning activities (Peter Berking, 2014).

This statement proves the important of software in terms of supporting alternative learning approach in education system and when mentioning software as learning support system, it is referring to the use of 
PowerPoint slide presentation until the use of web pages as learning references (Peter Berking, 2014). Even though software tools not only been develop for the sake of learning program only (it could be multi-purpose software tools), if educators use it as part of the e-learning activities, automatically the software tools will be considered as Authoring Tools. Authoring Tools like PowerPoint presentation more likely to be used in teaching Art History since it suits the learning environment as well.

Nowadays, because of the advancement of software, technology and gadgets, most e-content in Art History subject should implement physical interactive along with the used of software. In simple words, if the software requires students to participate by clicking or by moving around, the content in Art History will be delivering successfully.

\section{CONCLUSION AND RECOMMENDATION}

This research will give an idea for educators to develop better teaching methods by considering the interactive approach in their teaching materials. The adaption interactive concept will reduce issues among students when attending art history class. By using this e-content approach it will develop not only student's learning skill but will improves educator's method of teaching. This kind of alternative teaching method will definitely bring higher education into the next level due the application of this approach is still following the rules and regulation which is still related to teaching and learning process. The poor examination result of art history subjects will be change through the application of e-content in art history subject. This is because, the application of this alternative teaching method is based on the observation from the previous research, and as per stated by D.R. Garrison and Terry Anderson, e-learning has not been created to compromised the value of higher education, but it is to create the idealized community of inquiry (D.R. Garrison And Terry Anderson, 2003). Through this research, researcher would like to suggest method used in expanding this research which using quantitative method to develop the interactive e-content and using qualitative method to gather and to record audience feedback for improvement.

\section{ACKNOWLEDGEMENT}

The authors would like to express our gratitude to Department of Fine Art, Faculty of Art \& Design, Universiti Teknologi MARA, Perak Branch, Seri Iskandar Campus; The Ministry of Higher Education in Malaysia; and Research Management Centre, Universiti Teknologi MARA for providing and managing the fund from Academic \& Research Assimilation Grant (ARAS) [ref. no. 600-RMI/DANA 5/3/ARAS (53/2015)]

\section{REFERENCE LIST}

Allison Littlejohn and Chris Pegler, (2007). Preparing For Blended E-Learning: Understanding Blended And Online Learning (Connecting With E-Learning), Published By Routledge

Anahit Ter-Stepanian, (2011) Making Art History Come Alive In The Online Classroom, International Conference The Future Of Education

Azlan Abdul Aziz, Che Nor Syairah Che Rozaid, Mohamad Ibrahim and Mohd Nor hajar Hasrol Jono, (2014). Formulating E-Content Guidelines for Adults Learners in distance Education Program, International Journal of Education and Research

Beatrice Ghirardini, (2011). E-Learning Methodologies A Guide For Designing And Developing E-Learning Courses, Publishing Policy And Support Branch, Office Of Knowledge Exchange, Research And Extension, FAO, Viale Delle Terme Di Caracalla, 00153 Rome, Italy.

Charles M Reigeluth, Allison A. Carr-Chellman, (2009) Instructional- Design Theories And Models Volume III, Taylor And Francis Publishers, London And New York

D.R. Garrison And Terry Anderson, (2003). E-Learning In The 21st Century. A Framework For Research And Practice, Routledgerfalmer 11 New Fetter Lane, London Ec4p 4ee

Dr. K.Nachimuthu, (2012) Need Of E-Content Developments In Education, Education Today, An International Journal Of Education \& Humanities, APH Pub, New Delhi, 
Epignosis LLC, (2014) E-Learning, Concept, Trends, Digital E-Book Www.Efrontlearning.Net

Elaine England and Andy Finney, (2011) Interactive Media-What's that?Who's involved?, ATSF White Paper-Interactive Media UK-@2002/2011 ATSF

Julia Murphy, (2007). 1001 Ideas For Teaching History, Publisher Bloomsbury Publishing Plc

Kevin Wong And Paul Lam, (2011). E-Books As Teacing Strategy -Preliminary Investigation, Ascilite 2011, Chinese University Of Hong Kong

Lizeron Eremias, R. Subash, (2013) E-Content Development: A Milestone In The Dynamic Progress Of ELearning, International Journal Of Teacher Educational Research (ljter) Vol.2

Moturi Srivinas, Prasada Rao, Digumarti Bhaskara Rao, (2004). Methods Of Teaching History, DiscoveryPublishingGroup (2004)

Nada Aldoobie, (2015) ADDIE Model, American International Journal Of Contemporary Research

No author indicates, What is eLearning?, (current). https://www.le.ac.uk/users/rjm1/etutor/elearning/whatiselearning.html

Patricia L Smith, Tillman J Ragan, (1999) Instructional Design : Second Edition, Bookjohn Wiley \& Son Inc

Peter Berking, (2014) Manual Bookchoosing Authoring Tools Advanced Distributed Learning (ADL) CoLaborataories Version 8.0, This Document Was Produced By Serco Services, Inc. Under OPM Contract OPM0207008 Project Code:02 EA3TTAN MP Vol. 3.

Rhona Sharpe and Greg Benfield, (2005). The Student Experience of E-Learning in Higher Education: A rivew of the literature, Brookes e-Journal of learning and Teaching.Volume 1 Issue 3

Snjezana Koren, (2014). Boring History, Boring Pupils: The Role Of History Teachers, Magazine Povijest 8

Swati Gupta, (2010) Traditional Vs. Modern Teaching Methodology, Bilingual Journal Of Humanities \&Social Sciences

Tonya Joosten, (2012). Social Media For Educators- Strategies And Best Practices, Jossey-Bass; 1 Edition (March 21, 2012)

Viera Boumová, (2008). Traditional vs. Modern Teaching Methods: Advantages and Disadvantages of Each, Master's Diploma Thesis Masaryk University Faculty of Arts Department of English and American Studies 